\title{
Rural Entrepreneurship through Electricity
}

Abstract: Rural electrification in Nepal is supported mostly by bilateral donors and banks as a top down supply driven activity with emphasis on generation and transmission, but not focusing on supplying electricity to the maximum number of rural people. In the past, rural electrification was awarded as political favors, leading to inefficiency. Further, it could not further the efficient development of energy, which requires marketing innovation. The result of such rural power distribution created a condition where everybody was at fault and a loser.

An innovative approach involving the rural communities has the potential of reversing this trend, and allowing communities themselves to manage local rural electrification systems. This approach has raised public interest in Community Development and Rural Electrification with the establishment of about 450 rural electricity communities in Nepal. In anticipation, these communities are willingly contributing $20 \%$ matching fund of total rural electrification cost. Since 2003 to 2008, 189,770 households (about 45,000 households annually) have gotten access to electricity in rural areas through the promotion of community-based electricity development. Clearly, this is a significant positive response from the rural population. Like community forestry before it, community rural electrification is also a success story in Nepal. The new approach has paved the way to gender equality. It helped to generate more economic activities, to activate productive end use of electricity, developed rural entrepreneurship and released the poorest of poor population from the 'bonds' of the old social structure.

Key words: Rural electrification, community involvement, community based organizations (CBO), rural entrepreneurship, delivery mechanism and ownership, Nepal

$\mathbf{T}$ he Government of Nepal (GoN) has recognized the major role of electricity in the development of the country and has promoted rural electrification as one of the key infrastructure elements indispensable to encouraging rural economic development. Rural Electrification (RE) in Nepal, however, is a top down supply driven activity. It does not couple well with the development of energy, as energy development requires marketing innovations. The key to the marketing of energy development is the extension of rural electrification. It is also true that bilateral donors and banks have supported it, but that it is running sluggishly. It has created a major challenge to the GoN and to the Nepal Electricity Authority (NEA). At present, $48.5 \%$ of the total population is electrified (Adhikari, 2007-08:62). The population composition of rural household is $84 \%$ (CBS, 2001), out of which only about $8.6 \%$ have been electrified This picture truly reflects the miserable conditions of rural electrification. Considering the average annual population growth of $2.27 \%$, the annual rural electrification growth

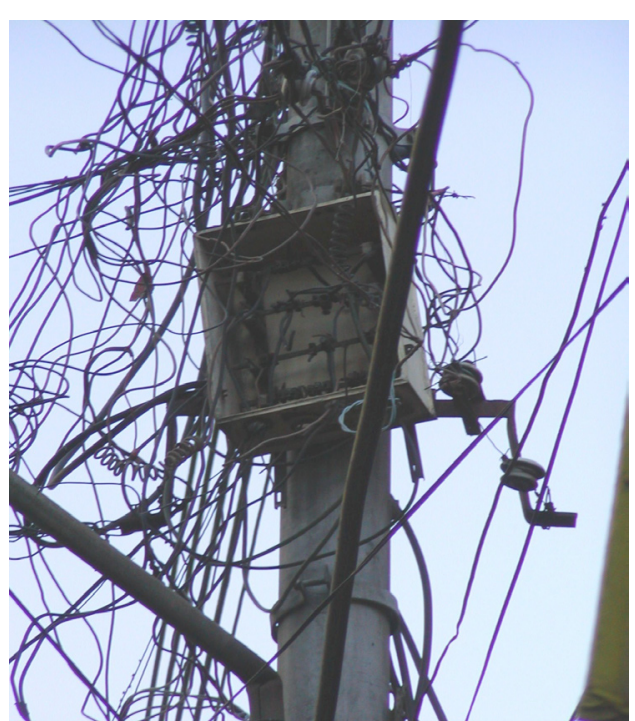

An overburden Distribution Line develop entrepreneurship in rural community.

\section{Challenges}

Excessive distribution loss has made the cost of electricity high; but it is pilfering by individuals and groups that has caused the honest user to suffer. Due to this theft, electricity supply services to rural persons is not accessible nor it is cheaper as compared to urban areas, when the tariff is same for both. Similarly, the prospects for extending rural electrification using existing overburdened power sources are not encouraging to NEA, as it is a commercial entity. Irrational decrease and increase in demand of rural electricity, in both peak and off-peak hour leads to low return and high service costs. Further, investment and management inefficiencies plus rural electrification often awarded as political favors, lead to inefficient service and less growth in coverage.

The general perception in the NEA is that due to the subsidized is $1 \%$. Nepal's annual per capita energy consumption is 86.71 kWh (NEA Fiscal Year-2007/8), among the lowest in the world. Electricity comprises less than $2 \%$ of the total energy consumption in the country (CBS, 2004). Experiments on different projected approaches have not been able to meet the growing demand commensurate with population and income growth; and have been unable to electricity to the commercial and industrial sector and high rates of power purchase from independent power purchasers, the financial health of NEA is poor. In turn, this makes for poor maintenance, especially of rural distribution infrastructure, and lower rates of capacity addition in the system. This in turn, triggers dissatisfaction among 
consumers by being unable to meet the growing demand of communities. And this makes the government, the NEA and the public dissatisfied. Poor rural power distribution in rural areas provokes a condition where everybody is at fault and everybody is a loser.

\section{Mission}

The system is owned by the people and managed by experts. Demand driven rural electrification with new technology envisages the reduction of operational cost of NEA through the development of rural entrepreneurships. The result should be a better product and higher quality of electricity services, providing a win-win situation to consumer and service provider alike. The rational of the mission is to provide electricity to rural people earlier than expected, to share the benefit with them, to meet community expectation and to share their wisdom through advanced rural electrification technology.

The mission based on these views of rural community participation through the process of 'Community Rural Electrification' was adopted in 2003. Community Electricity Distribution Bye Laws - 2060 (2003) was enacted. This innovative approach was based on the idea of involving the rural communities, with their commitment first in cash. This would bring them power from the grid and would facilitate handing responsibility for rural electrification, and for them to manage energy distribution. Implementation of rural electrification scheme is completed through competitive bidding and short listing of pre-qualified national contractors. It is important that such a local scheme is not physically launched unless full funding for its completion is secured.

Construction of the schemes is on turnkey contract basis, where the contractors are implementers of the rural electrification scheme with responsibility for overall completion, quality and performance, as opposed to how it was traditionally done through supply of materials and labour work for construction separately achieved. It is common knowledge that the traditional system has resulted in uncompleted schemes, over stocking of inventory, high overhead costs in storing and handling inventory, inappropriate and untimely capitalisation, and severe accountability problems leading to the waste of funds.

\section{Community developments}

The present community based RE (CBRE) is the result of refinement of past several years of experiences from fully paid Donor assisted RE programs to present days community sharing of $20 \%$ of the cost. The community groups are given training in organizational development and technical training to their staff. At present, community based $\mathrm{RE}$ programs are ongoing in 52 districts and financed by the GoN (to the tune of Rs. 600 million annually). The size of the each program is varied; but mostly each program consists of 150-200 households which costs arround Rs. 15 to 20 million each. As the demand is increasing it will be a challenge to the government to allocate the $80 \%$ matching fund. For the implementation of CBRE there are three divisions located in three different places in the country with total staff of only about 27-28 persons.

The residents of rural villages, tired of the unfulfilled expectations and promises to have electricity under the traditional system, are now getting together to establish new electricity cooperatives. These actions have accelerated general public interest in Electricity Community Development and rural electrification, with the establishment of about $45 \mathrm{O}^{2}$ rural electricity communities (excluding the Donor assisted programs). In anticipation, the communities willingly contribute $20 \%$ matching fund against the $80 \%$ contribution from the GoN of the total rural electrification cost. On average, 45,00o beneficiary households have been added annually. The program has enriched the adaptive capacity of local communities in remote rural areas to cope with the negative impact of environment change and helps communities meet their basic need for energy services. (And, not least, it helps towards the achievement of one of the nation's Millennium Development Goals.)

\section{Sense of ownership}

Thus, involvement of community in rural electrification scheme has developed the real sense of ownership. The $20 \%$ community participation is the prime beauty of the program and causes a real sense of ownerships. Rural people are now very much conscious about damage or loss of community assets. This is not the case, however, where the NEA alone is operating the distribution system. Thus, the rural electrification program is not only creating a sense of social ownership, but also enhances the safety and security of national assets. There used to be a general attitude among the population of "Why should I bother?" And, there used to be unhealthy illegal competition between people to store or damage national assets in their own interest.

\section{Reduction of distribution system losses}

As mentioned above, theft is the main cause of excessive distribution loss, which is punishable by law. This situation mainly happened in NEA-owned distribution areas; whereas, in community-owned electricity distribution areas, local people have discarded habits of electricity theft. Thus, the program is creating a favorable environment for respectful life in rural areas. People of 'community electricity owned areas' are comparing their social status with other 'NEAowned electrified areas', and have felt great satisfaction that they are honest and conscious citizens of Nepal. They have expressed these feelings on many occasions in seminars and workshops. Wholehearted support and feelings of selfmotivation are further attractions of the program.

\section{Clean energy and rural entrepreneurships}

In remote and rural parts of Nepal, diesel engines are the only source of power for rice, flour, and oil-mill power, which is difficult to buy and carries high transport costs in remote area. Electricity has replaced diesel, thus saving both time and money. In addition, the local people are getting clean energy in their villages. Many people are now recharging their batteries and grinding their corn using electricity. 
The lowland Terai region of Nepal is fertile farmland for paddy, corn and wheat crops; but, unfortunately, it lacks irrigation facilities in many areas. Now there is electricity and people are using five horsepower single-phase motors to pump ground water through shallow tubewells. This is common in the Terai, while in hill areas the villagers usually construct huge water storage tanks and fill them with river water by pumping, for irrigation purpose.

The story is not limited up to wheat and paddy irrigation. People are using kitchen gardens supported by irrigation through one-half or one horsepower single-phase motors, and also hand pumps, for tapping ground water. Thus, this program also has generated local employment in the villages. It has also encouraged the development of irrigation facilities and, therefore, rural farmers are able to produce their own farm produce for local consumption, and to market in urban areas.

These entrepreneur developments are not limited to the agriculture sector. They have also spread to local development and the construction of new roads. In most rural and remote areas manual transportation is only way to transport electrical equipment and construction material to construction sites. The rural electricity communities are now mobilizing contractors who are responsible for construction of new rural electrification system. They are also joining together to turn foot trails into motorable roads using the local resources only. Thus, transportation of electrical construction material has become cheaper. The contractors are contributing to rural communities in construction of roads. In Gulmi District, for example, 200 kilometers of rural roads have been constructed. Stakeholders have contributed NRs. 400 million in whole of the RE program as their community's $20 \%$ share of the cost.

\section{Cooperation}

Another positiveindicator is that forest user groups, generally regarded as a highly successful modality for community development in Nepal, have now joined this program by contributing some of their income to rural electrification. This has not only helped to curb the illegal export of forest products, but has also encouraged conserving local forests. Nowadays community leaders are coordinating with the Department of Forests to reforest the areas, and many communities have institutionalized watershed development programs and care for trees. Among the results are reduced use of firewood, increased tree planting that reduces carbon dioxide emissions, and carbon sinks in the environment.

This new innovative program is so popular that Village and District Development Committees (VDCs and DDCs), forest communities, and international and local non-government organizations (I/NGOs) are coming in as partners, giving help by providing staff development training and necessary tools and equipment for operation and maintenance. These actions have great relevance and importance, because they aid in developing sustainable rural electrification programs that will help to supply electricity to vast majority of rural population as per their expectations.
The following are the expected impact from rural electrification:

- Increased rural electrification coverage: additional 45,000 rural households are getting electricity annually.

- Increased consumer connection rate: $98 \%$ to $100 \%$ rural connection in community area.

- Increased per consumer consumption from 14 to 38 $\mathrm{kWh}$.

- Improved load factor.

- Reduced operation and maintenance costs.

- Reduced distribution losses (up to $12 \%$ average whereas NEA's total average loss is above 26\%).

- Low tariffs to the customers: up to NRs. 5-6/kWh (NEA sells at Rs 3.50 per kWh in bulk+ Rs. 0.10/kWh rental fee)

- Improved service reliability.

- Increased revenue for the NEA.

- Improve socio-economic and gender status in rural areas.

For better and additional impact, communities are motivating their member for $100 \%$ consumer connection by introducing new domestic electrical appliances on the installments basis. Shops are opening in community area. Local area youth are being employed as a working group. And, overhead costs are low in comparison to the NEA. These are the success outcomes of the program, and have promoted marketing activities in the communities. It has enabled a larger section of rural people propagating the community rural electrification distribution system. It has also created their own wide-ranging, feasible and suitable local market of national resources.

On the social side, for the households with electricity supply the following improvements have been noted: increases in average annual income; average annual household expense on education; average annual health care expenditure generally for housewives; adult literacy rates, and quality of education and in the socio-economic status of women; and in-migration into electrified village.

\section{Final word}

Many schemes in developing country fail due to lack of entrepreneurship and opportunity for creating forward/ backward linkages and the market. The upliftment of rural economies comes through creating markets based on commitment to the community irrespective of caste, creed or gender, and with advance commitment by advance in cash. Rural economies based on agriculture typically face scarcity of resources and partial or major underemployed. This rural electrification scheme of access to clean energy with community involvement has created rural entrepreneurship, marketing innovations and social responsibility, with opportunities to develop other product/ service areas powered by electricity.

Electricity plays a pivotal role in the economic development of a nation. Availability of electricity assists in the overall development, whereas consumption reflects the economic status of a nation. Therefore, to supply electricity 


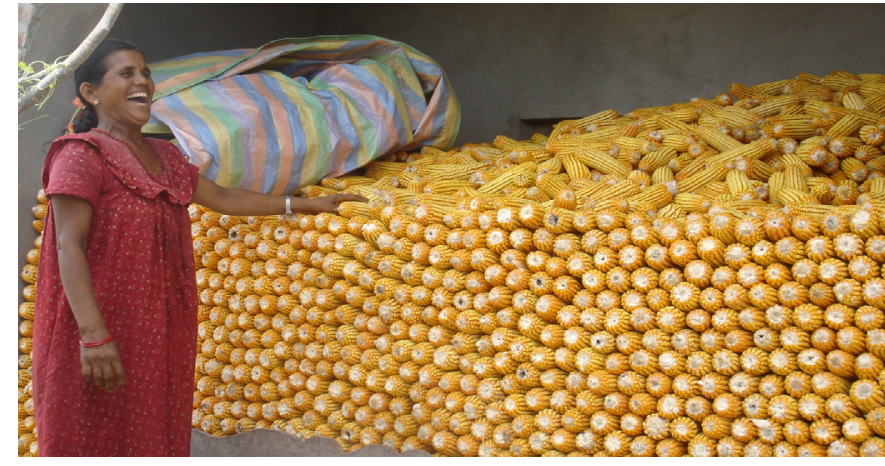

Prosperity through Irrigation

it is necessary to convert available water resources into electric power, which will play an important role in the overall development of the country. Urban people are major consumers of the current electricity supply, whereas the majority of country's population reside in rural areas. Many agro-industries, irrigation and cottage industries are focused on rural areas. The country's overall development depends on development of rural area. Therefore, regional development is possible only through equitable consumption opportunity of electricity in urban and rural areas alike.

When consumer communities become active stakeholders, it can be demonstrated that electricity distribution and supply systems function more efficiently and provide better return on investment to the institutions and to the nation. Rural electrification has given impetus to entrepreneurship in the rural areas. Nepal's rural electrification has been a success story.

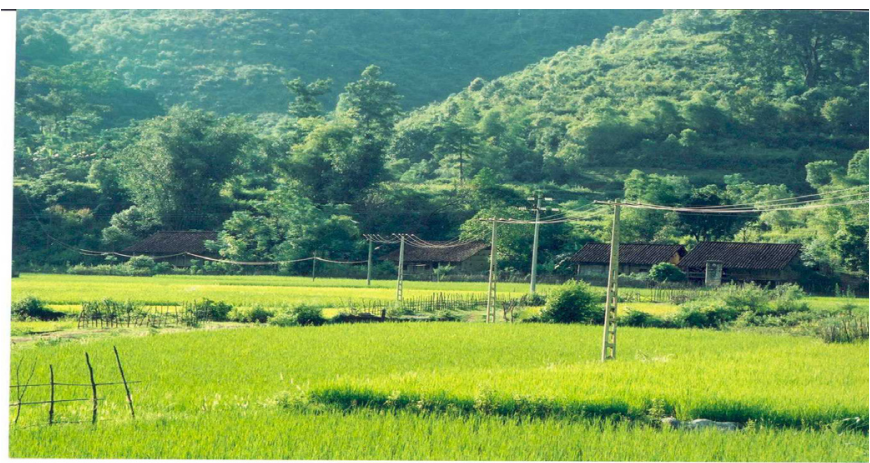

Newly constructed distribution lines in rural areas
Ram Chandra Pandey is the Director of the Cross Border $400 \mathrm{kV}$ Transmission Line Project for the Nepal Electricity Authority (NEA). He is a founder member of the Rural Energy Access Network of the South Asia Regional Network for Energy (SARI/E). As project manager he initiated and successfully completed the Kailali Kanchanpur Co-operative Based Rural Electrification Project in Nepal's Kailali-Kanchanpur District during 1997-2003. Mr. Pandey has also served as a Founder Director of the NEA's Community Rural Electrification Project (2003-2008) and successfully implemented the government's new Community Based Rural Electrification Approaches and Concept. He is NEA Representative Member on the Board of Directors of Nepal's Salleri Chialsa Electricity Co. Ltd. (SCECO). And is a recognized guide in community development and rural electrification programs of Nepal.

Corresponding address: rcpandey@mos.com.np

\section{References}

Adhikari, Kapil Deo, 2007-08, 'NEA half yearly bulletin', Vidyut (Kathmandu), vol. 10, no.1 (Bhadra 2065VS).

CBS, 2001, 'Basic facilities in urban and rural areas, Nepal', Population Monograph of Nepal, Kathmandu: Central Bureau of Statistics and National Planning Commission Secretariat.

CBS, 2004, Statistical Pocket Book, Nepal, Kathmandu: National Planning Commission Secretariat.

NEA Fiscal Year 2007/8- A year in Review, Page no. 59, Total electricity sales $2348.91 \mathrm{GWH}$, www.nea.org.np

\section{(Footnotes)}

${ }^{1}$ This is the revised article of the one published in "Vidhut" in 2065 (Aug-Sept, 2008)

2 Eventhough about 450 communities have been registered, the actual implementation of CBRE is more than 230. 